\title{
Human resource management: the promise, the performance, the consequences
}

Article

Accepted Version

Brewster, C., Gooderham, P. N. and Mayrhofer, W. (2016) Human resource management: the promise, the performance, the consequences. Journal of Organizational Effectiveness:

People and Performance, 3 (2). pp. 181-190. ISSN 2051-6614 doi: https://doi.org/10.1108/JOEPP-03-2016-0024 Available at https://centaur.reading.ac.uk/66087/

It is advisable to refer to the publisher's version if you intend to cite from the work. See Guidance on citing.

To link to this article DOI: http://dx.doi.org/10.1108/JOEPP-03-2016-0024

Publisher: Emerald

All outputs in CentAUR are protected by Intellectual Property Rights law, including copyright law. Copyright and IPR is retained by the creators or other copyright holders. Terms and conditions for use of this material are defined in the End User Agreement.

www.reading.ac.uk/centaur 
Central Archive at the University of Reading

Reading's research outputs online 


\title{
Human Resource Management: The Promise, The Performance, The \\ Consequences
}

\author{
Chris Brewster \\ Paul N. Gooderham \\ Wolfgang Mayrhofer
}

Schuler and Jackson (2005) trace the origins of the concept of HRM to mid-1970s USA. By the mid-1980s it had displaced the term 'personnel management' - "partly a file clerk's job, partly a housekeeping job, partly a social worker's job and partly fire-fighting to head off union trouble" (Drucker, 1989:269) - almost completely. In one version, HRM promised to deliver systems that would boost firm performance (Fombrun et al. 1984) while in another it would do so through enhancing employee influence (Beer et al., 1984). Thirty years later, we observe that the promise of HRM remains precisely that, a promise that to date has been unfilled. In a recent analysis of the state of HRM, the UK's Chartered Institute of Personnel and Development (CIPD) concluded:

Closely linked to the need for greater collaboration (with stakeholders)...is the need for HR to communicate a credible case for how their HR strategy links directly with the business strategy....Most HR leaders believe their HR strategy helps their organization achieve its future key priorities, but other business leaders are not convinced (CIPD, 2016:32).

However, belief in the value in HRM remains undimmed. The CIPD (2016: 5) are asking for a discussion of "how HR can further increase its impact on long-term business performance." Likewise, Ulrich (2013: 16-17) argues, “...executives must see their human resource practices as a source of competitive advantage" and therefore set about designing and delivering "the human resource management practices that can... deliver results".

We will argue that the difficulty in converting belief in HRM into results is in part due to academic researchers. First, while seemingly reassuringly supportive of the HRM project, the most influential products of academic research are actually disappointing not just in terms of their practical value but also in terms of their external validity. Second, that the 'dominant research orthodoxy' in HRM has failed not only in terms of its narrow firm performanceoriented agenda, but also the tenets of its agenda have contributed to serious levels of employee dissatisfaction and to the failure to deal with pressing global issues. In trying to 
appeal to the senior management team, both HRM practitioners and academics have been myopic with regard to other stakeholders, including society in general (Beer et al, 2015).

\section{The dominant research orthodoxy in HRM}

We could have looked at a vast number of studies of HRM (see e.g. Jackson, Schuler \& Jiang, 2014) or, as we preferred to do, just the 16 most cited journal articles in the field ${ }^{\mathrm{i}}$, but the overall conclusion is the same. The dominant focus of HRM research has been that of 'strategic HRM', that is a focus on the impact of HRM on firm performance. In our list of the most prominent articles in the field of HRM in Table 1, 13 articles were in this category and a fourteenth comprised a meta-analysis of 92 strategic HRM studies.

\section{Table 1 The Most Cited HRM Journal Articles (ranked by magnitude of citations)}

\begin{tabular}{ll} 
Huselid & 1995 \\
MacDuffie & 1995 \\
Delery \& Doty & 1996 \\
Arthur & 1994 \\
Ichniowski, Shaw \& Prennushi & 1997 \\
Delaney \& Huselid & 1996 \\
Youndt, Snell \& Dean & 1996 \\
Huselid, Jackson \& Schuler & 1997 \\
Guthrie & 2001 \\
Batt & 2002 \\
Snell \& Dean, Jr. & 1992 \\
Collins \& Smith & 2006 \\
Rosenzweig \& Nohria & 1994 \\
Combs, Lie, Hall \& Ketchen & 2006 \\
Cappelli \& Neumark. & 2001 \\
Lepak, \& Snell & 2002 \\
\hline
\end{tabular}

Not least because they were published in prestigious and therefore highly influential journals, it is reasonable to suggest that the findings of these articles constitute the dominant orthodoxy in HRM. As many as ten were published in the Academy of Management Journal, including the most cited article, (Huselid, 1995), which has accumulated approximately 1,700 citations. To qualify for joint $15 / 16^{\text {th }}$ place required a 'mere' 230 citations. The mean number of citations was 573 .

It is equally reasonable to claim that the dominant research orthodoxy bears the imprint of the USA. It is striking that as many as 12 of the articles sampled firms exclusively within the 
USA. We identified only one paper that drew on a firm sample outside of the USA and that was New Zealand (Guthrie, 2001).

However, the predominance of US-centric studies and therefore the questionable crossnational generalizability of the dominant research orthodoxy is arguably a minor problem in relation to the lack of consensus on how to operationalize HRM and firm performance. Delery and Doty (1996) distinguish three perspectives on how researchers conceive HRM. The 'universalistic or best-practice perspective' views certain HRM practices as always delivering superior firm performance. The 'contingency perspective' views the effectiveness of HRM practices as influenced by the degree to which they are consistent with other aspects of the organization such as the strategic position of the firm. The 'configurational approach' (an element of the universalistic perspective) is concerned with the internal consistency of the organization's HRM policies or practices and views certain tightly coupled systems or 'bundles' of aligned HRM practices (rather than single practices) as enhancing firm performance.

Table 2 indicates that while the universalistic perspective has been the most widespread, within the dominant research orthodoxy, there are examples of all three approaches. Further, as some studies employed more than one approach it should be possible to decide on which of the approaches to conceiving HRM is the superior. Delery and Doty (1996) find virtually no support for the contingency perspective, very limited support for the configurational but strong support for the universalistic perspective. Delaney and Huselid (1996) found support for the universalistic perspective. However, Cappelli and Neumark (2001) find not only no evidence for the configurational perspective but only moderate support for the universalistic.

Table 2 Distribution of perspectives on how HRM is conceived in the most cited HRM journal articles

\begin{tabular}{lr} 
& $\mathrm{N}$ \\
Only the universal & 8 \\
The universalistic \& configurational & 2 \\
Only the configurational & 2 \\
The universalistic \& contingency & 1 \\
The contingency \& configurational & 1 \\
Only the contingency & 0 \\
All 3 perspectives (Delery \& Doty, 1996) & 1 \\
\hline
\end{tabular}

One article did not measure HRM as such but the capabilities of HR managers 
However, even the notion that there may be at least some moderate support for the universalistic perspective is problematic. This is because what Table 2 does not reveal is that within each perspective there are significant differences in operationalization. Within the universalistic perspective, for example, we observe that while Delaney and Huselid (1996) grouped 'progressive HRM practices' into six variables, Cappelli and Neumark (2001) employed seven sets of 'high performance' work practices. With regard to the contingency perspective, we note that while MacDuffie (1995) employed flexible production versus mass production, Delery and Doty (1996) used rate of product/ market innovation. The approaches to operationalizing the configurational perspective are equally diverse: MacDuffie (1995) employed two additive bundles of 'innovative HRM practices', while Delery and Doty (1996) used a different two 'ideal employment systems'.

In pursuit of demonstrating that HRM contributes to firm performance, it is also remarkable how little consistency there is in defining the concept of firm performance. Of the 13 articles that have a 'strategic HRM' perspective, seven of them measured organizational performance, two financial performance and four both. Organizational performance was operationalized in a variety of ways: for example, Arthur (1994) conceived of it as labour hours per ton of steel, scrap rates and employee turnover, while Guthrie (2001) employed measures of employee turnover and productivity. Financial performance was also measured in various ways including return on equity and return on assets (Delery \& Doty, 1996) and revenue from new products and sales growth (Collins \& Smith, 2006). Only two of the thirteen articles (Ichniowski et al, 1997; Cappelli \& Neumark, 2001) employed panel-data. Thus, for the most part the design of the studies comprising the dominant orthodoxy is based on cross-sectional data making it problematic to determine cause and effect. It is noticeable that the measures are all of short-term effects.

Yet another cause for concern is the HRM-performance link. For the most part the thirteen strategic HRM articles examine the relationship directly. There is therefore little in the way of theorizing as to the mediating mechanisms. However, there are two exceptions: Batt (2002) uses employees quit rates as a mediator while Collins and Smith (2006) include very different mediating variables: social climate, knowledge exchange and combination.

A final cause of concern is the general absence of external moderating variables. Batt (2002) includes customer segment and Combs et al. (2006) industry (manufacturing versus service). With the exception of MacDuffie (1992) who finds '[a] "Japan" effect', however, the use of national context is absent from what is a US-centric dominant orthodoxy. We have to look to 
our own research network, Cranet, to find studies that have taken national context seriously. For example, in a multi-country analysis of firm performance Gooderham, Parry and Ringdal (2008) found that the overall effect of HRM on performance was relatively modest while country of location was a relatively important source of variation in performance. Given the significance of national business systems as well as national economic conditions for firm performance, we would argue that is this is hardly surprising. However, this rather obvious insight is absent from the dominant strategic HRM orthodoxy in which firms are assumed to exist in societal voids.

Since citations are incremental and increase over time, the two most recent articles in Table 1 were published in 2006. One possible objection to our analysis of the dominant orthodoxy is that perhaps mainstream HRM researchers since 2006 have recognized and responded to its inadequacies. Thus, we conducted a second literature search among post-2006 journal articles. Our search revealed two relatively well-cited recent journal articles, Sun, Aryee and Law (2007) and Chen and Huang (2009). Apart from the location of the studies - neither drew their data from the USA - both studies displayed substantial continuities with previous work. Sun et al. (2007) used cross-sectional data to measure the impact of 'high-performance human resource practices' on organizational outcomes (turnover and productivity) within a single service industry in a single country (China). Chen \& Huang (2009) also employed crosssectional data from a single country (Taiwan) in a study that examines the relationship between strategic HRM practices and firm innovation performance. Unlike the majority of the studies in Table 1, Chen and Huang employ a mediator and uniquely Sun et al. employ both mediating and moderating variables, including local rates of unemployment. However, both employ cross-sectional data, use their own operationalisations of HRM and, at least partly, firm performance, and neither consider national context. In other words, the dominant orthodoxy is alive and well.

The dominant orthodoxy in HRM is fixated on meeting the needs of owners of businesses. We are unconvinced that researchers operating within the dominant orthodoxy have demonstrated much of tangible value to that group. Certainly, senior managers, their agents, remain unconvinced that HRM adds much in terms of firm performance (CIPD, 2016). This failure is compounded by the fact this this research focus has precluded considerations of outcomes for other stakeholders. 


\section{HRM, performance and the non-owner stakeholders}

The HRM/ performance literature that we have reviewed so far is based on an assumption that performance is defined as the short-term financial performance of the organization and a second assumption that the sole role of HRM is to contribute to that. Even the literature that examines more proximate performance is based on this assumption: the purpose of HRM practices that enhance employee satisfaction or motivation is to change behaviour in ways that will eventually benefit the financial results of the business. That means that people, in the words of Sparrow and Hiltrop (1994: 7) are "to be obtained cheaply, used sparingly, and developed and exploited as fully as possible in accordance with the demands determined by the overall business strategy." The existing HRM/ performance debate, in short, takes place within a narrow shareholder or owner approach to HRM.

Such a focus has the advantage of fitting in nicely with the 'self-help, neo-liberal' philosophy that draws a straight line between managerial action and results and it makes measurement of at least one end of the HRM/ performance equation less debatable. It fits too with the simple yes/no hypotheses required by the 'proper science' approach (Beer et al, 2015: 430) of the top management journals. However, it fails to address the contested and contexted nature of HRM.

First, HRM is, unlike many other areas of management, contested. One of the two seminal texts that we mention above (Beer et al, 1984) identified a range of stakeholders with an interest in the (for these authors, particularly the long-term) outcomes of HRM. These interests may well not be aligned and may even be at odds. The analysis was reaffirmed by one of the leading figures in that text more than thirty years later (Beer et al, 2015). Owners of businesses are important stakeholders for HRM, but there are others (Beer et al, 2015); managers at all levels, employees, their representative organisations, their local community, consumers, governments and society at large are all stakeholders. What they think about organisations affects organisational legitimacy (Suchmann, 1995) and what organisations do affects them. Of course, to some degree these interests may align - it is in the interests of most of them, for example, that the organisation remains successful: that it provides profit (or the achievement of mission in some cases) for the owners, prestige and bonuses for the managers, secure employment and salaries for the employees and union members, and for the local community, goods and services for consumers, taxes for governments and support for the society at large. But the interests of these stakeholders will also to some extent diverge: how, for example, will the financial income of the organisation be divided? In HRM, every decision on recruitment, training and performance management will benefit and/ or 
disadvantage some stakeholders more than, or at a cost to, other stakeholders. The notion that HRM can be value-free or neutral is wrong.

Second, HRM is contexted. In contrast to the universalistic view of HRM, it seems obvious to us that not only does HRM vary with context, but that it should vary and it will create better performance, however defined, if it does so vary: HRM in a small family business is different from that in a giant multinational, HRM in a school is different from that in a factory, HRM in Pakistan is different from that in Canada. For us, HRM clearly works quite differently in each context - attempts to draw lessons about HRM that apply across contexts are foolish. To link this comment to our first point in terms of the non-owner stakeholders, the rights, responsibilities and general salience of stakeholders varies with country (Brewster \& Mayrhofer, 2012).

Of course, there have been studies of HRM that have examined the contested and contexted nature of HRM, but they have been too few and they have made too little impact. Such papers do not fit easily into the prevailing 'proper science' orthodoxy of the leading academic journals and consequently find it hard to be influential. However, they more closely reflect the reality of the stakeholders in HRM and we call for more such papers.

If there has not been enough discussion of context in HRM and little discussion of the interests of stakeholders such as employees, there has been almost nothing about the interests of the wider world.

\section{Societal Stakeholders: the sound of silence}

Although written two decades before the birth of HRM as an academic subject, Simon \& Garfunkel's title 'The Sound of Silence' is a broadly accurate description of the state of HRM when it comes to the big social questions of societies around the globe. This applies to issues that are at the heart of HRM: the quality of life of many employees is poor or is being diminished by exploitation, work intensification, surveillance, gross inequalities of treatment, insecurity, zero-hours contracts and the extensive blurring of responsibility for awful treatment behind supply chains. HRM research barely raises its voice.

And at the level of larger society, despite emerging HRM research on issues such as sustainability, (re-)migration, or the ageing workforce, we offer even less. In the face of the 
wide scope of global issues ranging from poverty and inequality to food and water issues, climate change, lack of pre-school and primary education, infectious agents, infant mortality to global terrorism and world-spanning criminal organizations, HRM remains, overall, suspiciously silent. We sense a fundamental problem: a self-inflicted procrastination of HRM research to 'traditional' HRM topics, often at the micro-level, and to limited segments of the for-profit and, to a lesser extent, the public administration world. By and large, HRM research has a very limited scope of issues that are dealt with. This is particularly the case when it comes to contributions in top tier journals, nowadays the primary, if not only, symbolic currency buying you an entry ticket into the upper echelons of the academic community. As a collective endeavour, HRM research up to now has been pretty timid when it comes to the big questions of the world, playing it safe within its own circles and tacitly following a collective credo along the lines of "We HRM researchers deal with the small section of the world we are pretty familiar with: dealing with simple input-output approaches to pleasant problems such as improving company performance through optimising classical HRM tools such as interview-based selection procedures or monetary reward systems".

This is a problem for both HRM and, more important, the world. For HRM, it clearly limits its credibility and standing within the overall chorus of scientific endeavours and disciplines. Yes, it is important to help companies understand what HRM can - and cannot - do in terms of performance. On a broader scale, however, this hardly meets the messy, complex reality of HRM's stakeholders and it is a long way from contributing to the big questions of the world such as governments, media, or philanthropic agencies. For the world, it cannot reap HRM's potentially important fruits as HRM research falls short of its potential in a twofold way: restricted scope and mono-dimensional source of inspiration.

This is a problem for HRM and, more important, the world. For HRM, it clearly limits its credibility and standing within the overall chorus of scientific endeavours and disciplines. Yes, it is important to help companies understand what HRM can - and cannot - do in terms of performance. On a broader scale, however, this hardly puts you centre-stage amongst the actors searching for contributions to the big questions of the world - the governments, media, or philanthropic agencies. 


\section{Getting centre-staged}

For governments, media, or philanthropic agencies HRM research falls short of its potential in a twofold way: restricted scope and mono-dimensional sources of inspiration.

First, restricted scope: much of HRM research is and has been done in classical organizational settings, in particular in larger, private sector, for-profit organizations and, to a lesser extent, in the public administration area. However, this leaves out many organizations that are key in understanding roots of major global issues as well as dealing with them. Therefore, we strongly urge the field to expand the scope of scientific investigation to organizations that try to cope with the large issues the world is currently grappling with. These organizations vary enormously in terms of size and scope (see Brewster \& Cerdin, 2016). They range from large UN or EU organizations such as UNCTAD, UNHCR, Frontex, or the European Central Bank to small NGOs such as Aggalia, set up by Papa Stratis helping refugees on the Greek island of Lesvos or AASARA - YWCA, a shelter home for women in distress in Mumbai-Byculla, India. Devoting more time and resources to researching these organizations, how they handle HRM and how they can improve can have a more or less direct effect on making the world a better place.

In addition, schools and universities, in particular business schools, are key levers for educating the next generation in ways that help solving global problems. While universities in particular have been the target of considerable organization theory research in terms of their functioning, for HRM research they are less prominent and not a focus. In-depth insight and actionable knowledge about personnel policies, recruitment and selection, training and development, and rewarding in these institutions, again varying widely and ranging from SubSaharan elementary schools such as the Sisters' elementary school in Lusaka, Zambia to world-renowned billion dollar universities such as Stanford in the USA can contribute to supporting the emergence of different types of people producing and passing on knowledge.

And what about the 'dark side' of society? It has had almost no place in the HRM research agenda. This ranges from the almost total failure to address what is known to be the widespread corruption within the private sector organisations that have been studied through to a failure to address organisations on the dark side. These latter include some regularly on the media's hit list of global problems: terrorist networks such as the Islamic State in the Middle East or Boko Haram in the North-East of Nigeria, drug cartels such as the Sinaloa cartel in the West of Mexico or the 'Ndrangheta in Italy's Calabria, criminal organizations with local bases but global operations such as the Sicilian Mafia or the Yamaguchi-gumi, a 
major Yakuza group from Japan, or various kinds of syndicates specializing on people trafficking in regions all over the world. Of course, such an endeavour does not allow armchair research and the obstacles that have to be overcome are tremendous. However, it is crucial - and feasible. Journalist sometimes break the wall of silence, so researchers can do so as well. Sources can include people who have managed to leave these organizations, their family members and friends and members of law-enforcement agencies. Better understanding of these organisations and their HRM issues, such as personnel policies, recruitment and selection, training and development, and rewarding/ punishing, are key to a supporting efforts to diminish their effectiveness.

Second, mono-dimensional sources of inspiration. The world has moved on to multi-channel and object-based sounds but HRM is stuck in mono. The major topics for HRM research that we identify above have either, as was the case with the debate we have highlighted on the HRM-performance link, been picked up from developments in the company world (for recent calls for research, see for example, the HRM contributions in Harvard Business Review 8/2015), or come from within the academic discourse itself, with calls for ever greater refinements of existing work. We note, in passing, that the increasing emphasis on 'impact' in the already convoluted academic monitoring system driven by the Higher Education Funding Council for England, is an attempt to create a different balance between these two sources but does not change them. In itself, there is nothing wrong with this type of research - except that in the long-run it is hardly sufficient. Why? In the light of the global needs for a better understanding of and answers to 'big' questions, it will just not suffice.

We call for HRM research that also looks for alternative sources of motivation (and money) for promising research areas that support the global quest for tackling pressing 'big' issues. For example, major institutions such as the United Nations or the World Economic Forum and, by and large, widely acknowledged think tanks such as the Brookings Institution in the US or the European Think Tanks Group regularly publish reports outlining major global challenges. Monitoring reports like that, taking up the pressing issues and translating these issues into guiding ideas for one's own research is key. To take one case, the Scientific Advisory Board to the Secretary General of the UN identifies the science-policy interface as one of top challenges for the future of humanity and the planet. This provides a broad field of scientific investigation. HRM researchers have developed expertise with respect to the work of professional specialists, the translation of research into practice, the functioning of multinational enterprises. They have a broad disciplinary background with HRM researchers 
trained in economics or business administration knowing about individual decision making rooted in calculable preferences, sociologists with their understanding of the importance of the social fabric for what goes at the organizational and societal level, or psychologists having an in-depth understanding of what drives people. This should be a huge opportunity for HRM research. In getting HRM centre-staged, that is our challenge.

\section{References}

Arthur, J. B. 1994. Effects of human resource systems on manufacturing performance and turnover. Academy of Management Journal, 37(3): 670-687.

Batt, R. 2002. Managing customer services: Human resource practices, quit rates, and sales growth. Academy of Management Journal, 45(3): 587-597.

Beer, M., Boselie, P., \& Brewster, C. (2015). Back to the future: Implications for the field of HRM of the multi-stakeholder perspective proposed 30 years ago. Human Resource Management, 54(3), 427-438

Beer, M., Spector, B., Lawrence, P. R., Quinn Mills, D., \& Walton, R. E. (1984). Managing Human Assets. The Groundbreaking Harvard Business School Program. New York: The Free Press.

Boxall, P. (2003). HR strategy and competitive advantage in the service sector. Human Resource Management Journal, 13(3): 5-20.

Brewster, C. and Cerdin, J-L (2016) Human Resource Management in Mission Driven Organizations, New York, Pearson Education

Cappelli, P., \& Neumark, D. 2004. External Churning and Internal Flexibility: Evidence on the Functional Flexibility and Core-Periphery Hypotheses. Industrial Relations: A Journal of Economy and Society, 43(1): 148-182.

Chen, C. J., \& Huang, J. W. (2009). Strategic human resource practices and innovation performance - The mediating role of knowledge management capacity. Journal of Business Research, 62(1), 104-114.

CIPD (2016). HR Outlook: Winter 2015-16: leaders' views of our profession. Published February 2016. http://www.cipd.co.uk/binaries/hr-outlook_2016-winter-2015-16leaders-views-of-our-profession.pdf 
Collins, C. J., \& Smith, K. G. 2006. Knowledge exchange and combination: The role of human resource practices in the performance of high-technology firms. Academy of Management Journal, 49(3): 544-560.

Combs, J., Liu, Y., Hall, A., \& Ketchen, D. (2006). How much do high-performance work practices matter? A meta-analysis of their effects on organizational performance. Personnel Psychology, 59(3), 501-528.

Delery, J. E., \& Doty, D. H. 1996. Modes of theorizing in strategic human resource management: Tests of universalistic, contingency, and configurational performance predictions. Academy of Management Journal, 39(4): 802-835.

Drucker, P. (1989). The Practice of Management. London: Heinemann Professional Publishing.

Fombrun, C. J., Tichy, N., \& Devanna, M. A. (Eds.). (1984). Strategic Human Resource Management. New York et al: Wiley.

Gooderham, P., Parry, E., \& Ringdal, K. (2008). The impact of bundles of strategic human resource management practices on the performance of European firms. The International Journal of Human Resource Management, 19(11), 2041-2056.

Guthrie, J. P. 2001. High-involvement work practices, turnover, and productivity: Evidence from New Zealand. Academy of Management Journal, 44(1): 180-190.

Huselid, M. A. (1995). The impact of human resource management practices on turnover, productivity, and corporate financial performance. Academy of Management Journal, 38(3): 635-672.

Huselid, M. A., Jackson, S. E., \& Schuler, R. S. 1997. Technical and strategic human resources management effectiveness as determinants of firm performance. Academy of Management Journal, 40(1): 171-188.

Ichniowski, C., Shaw, K., \& Prennushi, G. 1997. The effects of human resource practices on manufacturing performance: A study of steel finishing lines. American Economic Review, 87(3): 291-313.

Jackson, S. E., Schuler, R. S., \& Jiang, K. 2014. An aspirational framework for strategic human resource management. Academy of Management Annals, 8(1): 1-56.

Lepak, D. P., \& Snell, S. A. 2002. Examining the human resource architecture: The relationships among human capital, employment, and human resource configurations. Journal of Management, 28(4): 517-543.

MacDuffie, J. P. (1995). Human resource bundles and manufacturing performance: Organizational logic and flexible production systems in the world auto industry. Industrial and Labor Relations Review: 197-221.

Rosenzweig, P. M., \& Nohria, N. (1994). Influences on human resource management practices in multinational corporations. Journal of international business studies, 229-251.

Schuler, R. S., \& Jackson, S. E. (2005). A quarter-century review of human resource management in the US: The growth in importance of the international perspective. Management Revue, 16(1): 11-35.

Snell, S. A., \& Dean, J. W. (1992). Integrated manufacturing and human resource management: A human capital perspective. Academy of Management journal, 35(3), 467-504. 
Suchman, M. C. (1995). Managing Legitimacy: Strategic and Institutional Approaches Academy of Management Journal, 20, 571 - 610.

Sun, L. Y., Aryee, S., \& Law, K. S. (2007). High-performance human resource practices, citizenship behavior, and organizational performance: A relational perspective. Academy of Management Journal, 50(3), 558-577.

Ulrich, D., (2013). Human Resource Champions: The Next Agenda for Adding Value and Delivering Results. Harvard Business Press.

Wilton, N. (2010). An Introduction to Human Resource Management: Sage Publications.

'In April 2014 we employed "Web of Science" to identify the 15 most cited empirical journal articles that have as their focus HRM. As two papers tied for $15^{\text {th }}$, we extended the list to include 16 papers. Web of Science is highly correlated with Google Scholar. 